\title{
PENGARUH PENERAPAN STRATEGI CSR (CORPORATE SOCIAL RESPONSIBILITY) DALAM MENINGKATKAN CITRA PERUSAHAAN PADA PT. PERTAMINA (PERSERO) TAHUN 2018
}

\author{
Dina Anggresa Oktina, Eka Septiana Sari, Intan Angelina Sunardi, Laili Nurul \\ Hanifah, Vicky F Sanjaya \\ Program Studi Manajemen Bisnis Syariah Fakultas Ekonomi dan Bisnis Islam \\ Universitas Islam Negeri Raden Intan Lampung \\ intananjelinasunardi@gmail.com
}

\begin{abstract}
ABSTRAK
Tujuan penelitian ini untuk mengetahui pengaruh dari penerapan strategi CSR yang dilakukan oleh PT. Pertamina (Persero) melalui berbagai program yang dimiliki terhadap citra perusahaan tersebut. Metode yamg dilakukan dalam penelitian ini adalah metode/pendekatan kualitatif. Penelitian ini dibuat bukan untuk menguji hipotesis antara kedua variabel, melainkan untuk mendeskripsikan sejauh manakah program CSR yang sudah dijalankan oleh PT. Pertamina (Persero) dapat berperan dalam meningkatkan citra perusahaan tersebut. Data yang dikumpulkan merupakan data yang diperoleh dari annual report PT. Pertamina (Persero) pada tahun 2018 yang diambil dari IDX, artikel, dan dokumen lainnya. Teknik analisis data yang digunakan dalam penelitian ini menggunakan analisis komparatif (membandingkan hasil temuan peneliti dengan teori yang digunakan) dan meliputi pengumpulan data, reduksi data, penyajian data dan penarikan kesimpulan. Berdasarkan hasil analisis pada data yang diperoleh, strategi yang diwujudkan ke dalam program CSR PT. Pertamina (Persero) sudah dilakukan sesuai dengan visi, misi, prinsip dan strategi perusahaan yang ditetapkan oleh perusahaan itu sendiri. Hasil yang diperoleh dari penelitian ini menunjukkan bahwa secara keseluruhan penerapan strategi CSR yang dilakukan oleh PT. Pertamina (Persero) pada dasarnya memiliki pengaruh dan berperan aktif dalam meningkatkan citra, reputasi serta kredibilitas perusahaan. Dalam hal ini, hal yang harus dilakukan oleh PT. Pertamina (Persero) adalah mempertimbangkan untuk memperluas cakupan wilayah penerima program CSR yang mereka miliki, agar bukan hanya masyarakat yang berada di sekitar kantor pusat atau anak perusahaan saja yang bisa menerima manfaat dari setiap program CSR yang dijalankan, tetapi juga masyarakat secara keseluruhan.
\end{abstract}

Kata Kunci: CSR (Corporate Social Responsibility), citra perusahaan 


\begin{abstract}
The purpose of this research to determine the effect of implementing the CSR strategy carried out by PT. Pertamina (Persero) through various programs owned by the company's image. The method used in this research is a qualitative method / approach. This research was made not to test the hypothesis between the two variables, but to describe the extent of CSR programs that have been run by PT. Pertamina (Persero) can play a role in improving the company's image.The data collected is data obtained from the annual report of PT. Pertamina (Persero) in 2018 taken from IDX, articles and other documents.Data analysis techniques used in this study usecomparative analysis (comparing the findings of researchers with the theory used) and include data reduction, data presentation and drawing conclusions.Based on the results of the analysis of the data obtained, the strategy embodied in the CSR program of PT. Pertamina (Persero) has been carried out in accordance with the company's vision, mission, principles and strategy set by the company itself.The results obtained from this study indicate that the overall implementation of CSR strategies carried out by PT. Pertamina (Persero) basically has an influence and plays an active role in improving the image, reputation and credibility of the company.In this case, things that must be done by PT. Pertamina (Persero) is considering expanding the scope of the area of the recipients of the CSR programs they have, so that not only the people in the vicinity of the head office or its subsidiaries can benefit from each CSR program that is carried out, but also the community as a whole.
\end{abstract}

Keywords: CSR (Corporate Social Responsibility), corporate image

\title{
PENDAHULUAN
}

Seperti yang kitaketahui, saat ini CSR atau tanggung jawab sosial merupakansalahsatuaspekpentingdalammembanguncitradanreputasiperusahaan. bukan lagi sebagai pilihan bagi sebuah perusahaan untuk dapat berkontribusi kepada pihak-pihak yang memiliki hubungan dan keterkaitan dengan perusahaan, baik itu pihak yang berada di internal perusahaan maupun pihak yang berada di eksternal perusahaan. Tetapi, CSR sudah menjadi suatu kewajiban dan merupakan komitmen bagi setiap perusahaan untuk tetap peduli dengan lingkungan di sekitarnya agar kegiatan operasional perusahaan tetap berkelanjutan. Hal ini sesuai dengan regulasi yang terdapat di dalam Undang-Undang Republik Indonesia (UU RI) Nomor 40 Tahun 2007 mengenai Perseroan Terbatas (PT) dan UU RI Nomor 25 Tahun 2007 mengenai UU Perseroan Terbatas, yang menyebutkan bahwa setiap perseroan yang menjalankan kegiatan usahanya di bidang 
dan/atau bersangkutan dengan sumber daya alam diwajibkan untuk melaksanakan tanggung jawab sosial (CSR). Selain sebagai suatu kewajiban yang sudah diatur di dalam regulasi (UU), CSR juga bisa dijadikan salah satu strategi untuk menciptakan dan meningkatkan citra perusahaan. Lewat CSR inilah, setiap perusahaan dapat memunculkan dan membentuk stigma positif publik mengenai kegiatan usaha perusahaannya melalui berbagai program CSR yang mereka jalankan.

Salah satu perseroan yang melaksanakan program CSR untuk meningkatkan citra perusahaanya adalah PT. Pertamina (Persero). Sebagai salah satu perseroan yang bergerak di bidang penyaluran energi dan merupakan salah satu perusahaan milik kementrian BUMN, PT. Pertamina (Persero) juga melakukan tanggung jawab sosial (CSR) sebagai salah satu bentuk komitmen mereka untuk peduli terhadap lingkungan dan juga masyarakat, terutama yang terdampak aktivitas usahanya.

Secara lebih lanjut, CSR bermakna sebagai komitmen perusahaan atau organisasi untuk terus menerus bertidak secara etis, beroperasi secara legal dan berkontribusi untuk peningkatan ekonomi yang sejalan dengan peningkatan kualitas hidup dari karyawan dengan keluarganya, sekaligus juga peningkatan kualitas komunitas lokal dan masyarakat secara lebih luas (Rusdianto, 2013:7).

Pada intinya tanggung jawab sosial perusahaan (corporate social responsibility) adalah kewajiban organisasi bisnis untuk mengambil bagian dalam kegiatan yang bertujuan melindungi dan meningkatkan kesejahteraan masyarakat secara keseluruhan. Penerapan CSR yang baik akan memberikan manfaat positif bagi perusahaan, salah satunya adalah citra positif.

Menurut Rusdianto (2013), salah satu manfaat yang dapat diperoleh oleh perusahaan jika mereka melaksanakan CSR dengan baik adalah citra perusahaan yang semakin meningkat. Program CSR merupakan salah satu program sosial yang dijalankan dengan tujuan untuk mendirikan hubungan yang baik dengan masyarakat sekitar guna membangun citra yang baik bagi perusahaan, program CSR dapat diwujudkan dengan cara mengadakan kegiatan amal, bakti sosial, pengadaan beasiswa untuk kepentingan masyarakat luas yang dijalankan oleh perusahaan, dan berbagai tanggung jawab sosial lainnya yang memiliki tujuan untuk pemberdayaan dan pembangunan secara berkelanjutan.

Citra perusahaanmenurutJefkins (2016) merupakan suatu hal yang berkaitandenganperusahaanuntukmembanguncitraatau persepsi yang positif, yang 
dapatdikenaldanditerima di khalayakumum.Pada dasarnya PT. Pertamina (Persero) juga menganggap bahwa suatu bisnis dijalankan tidak hanya harus mampu mencari keuntungan semata, namun juga bagaimana perusahaan tersebut memiliki kemampuan untuk tetap bertahan dan selaras antara kepentingan sosial dan komersial yang dijalankannya.Terlebih lagi jika kegiatan usaha yang mereka jalankan tersebut bergerak di bidang yang berkaitan dengan pengadaan sumber daya alam seperti halnya kegiatan usaha yang dijalankan oleh PT. Pertamina (Persero) .

Penerapan tanggung jawab sosial (CSR) dirasa sebagai salah satu langkah yang tepat untuk dijadikan strategi dalam meningkatkan citra dari suatu perusahaan, selain memang sebagai suatu kewajiban yang harus dijalankan oleh suatu perusahaan. Penerapan CSR dianggap suatu keharusan yang wajib dilakukan oleh suatu perusahaan, terlebih lagi jika perusahaan tersebut ingin tetap berkelanjutan. Karena pada dasarnya, dengan melakukan CSR yang sesuai dan terarah suatu perusahaan dapat melihat sejauh manakah mereka dapat menjalankan komitmen mereka untuk tetap berkontribusi bagi pemberdayaan dan kesejahteraan baik terhadap lingkungan maupun masyarakat.

Lebih jauh lagi, penerapan CSR yang baik bisa dijadikan suatu strategi untuk bersaing dengan perusahaan lainnya. Karena di era seperti sekarang ini, semakin banyak perusahaan yang berlomba-lomba untuk mewujudkan program CSR yang baik untuk meningkatkan citra, reputasi serta kredibilitas perusahaannya masing-masing. Terlebih lagi jika dengan CSR tersebut bisa membawa dampak positif bagi perusahaan mereka, seperti peraihan reward atau penghargaan yang semakin menunjukkan bahwa memang perusahaan tersebut memiliki kemampuan untuk menerapkan program CSR sebaik mungkin sebagai salah satu strategi dalam meningkatkan pamor perusahaannya.

Berdasarkan latar belakang yang telah dijelaskan di atas, maka penulis memutuskan untuk melakukan penelitian dengan mengangkat judul yaitu,"PENGARUH PENERAPAN STRATEGI CSR (CORPORATE SOCIAL RESPONSIBILITY) DALAM MENINGKATKAN CITRA PERUSAHAAN PADA PT. PERTAMINA (PERSERO) TAHUN 2018", untuk mengetahui seberapa besar pengaruh dari penerapan strategi CSR yang dilakukan oleh PT. Pertamina (Persero) melalui berbagai program yang dimiliki terhadap peningkatan citra perusahaan tersebut. 


\section{TINJAUAN PUSTAKA}

\section{Corporate Social Responsibility}

Menurut UU No. 40 Tahun 2007 tentang Perseroan Terbatas, tanggung jawab sosial perusahaan adalah komitmen perseroan untuk berperan serta dalam pembangunan ekonomi berkelanjutan guna meningkatkan kualitas kehidupan dan lingkungan yang bermanfaat, baik bagi perseroan sendiri, komunitas setempat, maupun masyarakat padaa umumnya. Menurut Philip Kotler, CSR dikatakan sebagai discretionary yang dalam arti luas berarti sesuatu yang perlu dilakukan. Seandainya tidak dilakukan, akan berakibat merugikan diri sendiri (dalam hal ini maksudnya adalah perusahaan). Sedangkan, menurut World Business Council for Sustainable Development, CSR bukan hanya sekedar discretionary, tetapi suatu komitmen yang merupakan kebutuhan bagi perusahaan yang baik sebagai perbaikan kualitas hidup (Rachman et.al, 2011:15).

Arti lain dari CSR (Corporate Social Responsibility) adalah suatu tindakan atau konsep yang dilakukan oleh perusahaan (sesuai kemampuan perusahaan tersebut) sebagai bentuk tanggung jawab mereka terhadap sosial/lingkungan sekitar perusahaan berada. Contoh dari bentuk tanggung jawab itu dapat bermacam-macam, mulai dari melakukan kegiatan yang dapat meningkatkan kesejahteraan masyarakat dan memperbaiki lingkungan, pemberian beasiswa untuk anak tidak mampu, pemberian dana untuk pemeliharaaan fasilitas umum, serta sumbangan untuk desa/fasilitas masyarakat yang bersifat sosial dan berguna untuk masyarakat banyak, khususnya masyarakat yang berada di sekitar perusahaan tersebut. Corporate Social Responsibility (CSR) merupakan fenomena strategi perusahaan yang mengakomodasi kebutuhan dan kepentingan stakeholder-nya. CSR timbul sejak area saat kesadaran akan sustainability perusahaan jangka panjang lebih penting dari pada sekadar profitability.

Kegiatan-kegiatan CSR merupakan suatu keputusan strategis yang melibatkan semua sumber daya perusahaan atau suatu keputusan strategis yang menyeluruh. Kegiatankegiatan CSR dalam bentuk community development, charity, ataupun philanthropy yang saat ini berkembang di Indonesia masih merupakan kegiatan yang bersifat pengabdian kepada masyarakat ataupun lingkungan yang berada tidak jauh dari lokasi tempat dunia usaha malakukan kegiatannya. Sering kali kegiatan CSR belum dikaitkan dengan tiga elemen yang menjadi kunci dari pembangunan berkelanjutan, yaitu aspek keuangan, aspek 
sosial, dan aspek lingkungan yang biasa disebut triple bottom line. Sinergi dari tiga elemen tersebut merupakan kunci dari konsep pembangunan berkelanjutan (sustainable development).

\section{Konsep Triple Bottom Line dalam Penerapan Corporate Social Responsibility (CSR)}

John Elkington mengungkapkan konsep triple bottom line dalam penerapan CSR di suatu perusahaan, dimana jika perusahaan ingin terus berkelanjutan (sustainable), maka harus memperhatikan 3P, yaitu profit, people, dan planet. Konsep ini menjelaskan hubungan antar menjaga kelestarian sumber daya alam dan lingkungan (planet), keuntungan perusahaan (profit), dan menjaga hubungan dengan masyarakat umum maupun sekitar perushaan (people). Dimana profit merupakan satu bentuk tanggung jawab yang harus dicapai perusahaan dan merupakan orientasi utama dari sebuah perusahaan, seperti keuntungan. Sedangkan people, merupakan masyarakat yang berada di lingkungan sekitar perusahaan tersebut dan biasanya merupakan penerima langsung dari setiap program yang dijalankan oleh suatu perusahaan. Pada dasarnya masyarakat memiliki hubungan yang kuat dalam rangka menciptakan nilai bagi suatu perusahaan. Planet adalah lingkungan fisik yang ada di sekitar perusahaan tersebut yang biasanya merasakan dampak langsung dari setiap aktivitas yang dilakukan oleh suatu perusahaan. Setiap aktivitas perusahan yang menyebabkan kerusakan lingkungan tanpa ada penanganan lebih lanjut dari perusahaan terkait dan berlangsung terus menerus cepat atau lambat dapat menghancurkan keseimbangan lingkungan sekitar dan akibatnya akan berdampak buruk bagi perusahaan maupun masyarakat sekitar (Hadi, 2011:56-58).

\section{Manfaat Pelaksanaan Corporate Social Responsibility (CSR)}

Aktivitas CSR memiliki fungsi strategis bagi perusahaan, yaitu sebagai bagian dari manajemen risiko khususnya dalam membentuk katup pengamanan sosial (socialsecurity). Dengan menjalankan CSR, perusahaan diharapkan tidak hanya mengejar kuntungan jangka pendeknya saja, namun juga harus turut berkontribusi bagi peningkatan kesejahteraan dan kualitas hidup masyarakat dan lingkungan jangka panjang. Adapun manfaat CSR bagi perusahaan yang menerapkannya, yaitu: 
- Membangun dan menjaga reputasi perusahaan.

- Meningkatkan citra perusahaan.

- Mengurangi risiko bisnis perusahaan.

- Melebarkan cakupan bisnis perusahaan.

- Mempertahankan sumber daya manusia yang berkualitas.

- Kemudahan memperoleh akses terhadap modal (capital).

- Meningkatkan pengambilan keputusan pada hal-hal yang kritis.

- Mempermudah pengelolaan manajemen risiko (risk management).

Bila CSR mampu dijalankan secara efektif, maka dapat memberikan manfaat tidak hanya bagi perusahaan, melainkan juga bagi masyarakat, pemerintah dan lingkungan (Rusdianto, 2013:13).

\section{Model Pelaksanaan Corporate Social Responsibility (CSR)}

Konsep piramida CSR yang dikembangkan oleh Archie B. Carrol (1991) memberi justifikasi teoritis dan logis mengapa sebuah perusahaan perlu menerapkan CSR bagi masyarakat sekitarnya. Menurut Carrol, CSR adalah puncak piramida yang erat terkait, dan bahkan identik dengan tanggung jawab, filantropis. Setidaknya terdapat empat model CSR yang akan diuraikan sebagai berikut:

1. Tanggung jawab sosial ekonomi

Perusahaan harus dioperasikan dengan berbasis laba serta dengan misi tunggal untuk meningkatkan keuntungan selama berada dalam batas-batas peraturan pemerintah.

2. Tanggung jawab legal

Kegiatan bisnis yang dilakukan diharapkan dapat memenuhi tujuan ekonomi para pelaku dengan berlandaskan kerangka kerja legal maupun nilai-nilai yang berkembang di masyarakat secara bertanggung jawab.

3. Tanggung jawab etika 
Kebijakan dan keputusan perusahaan didasarkan pada keadilan, bebas dan tidak memihak, menghormati hak-hak individu, serta memberikan perlakuan yang sama untuk mencapai tujuan perusahaan.

4. Tanggung jawab sukarela atau diskresioner

Kebijakan perusahaan dalam tindakan sosial murni sukarela, didasarkan pada keinginan perusahaan untuk memberikan kontribusi sosial yang tidak memiliki kepentingan timbal balik secara langsung.

Ada empat pola yang umumnya diterapkan oleh perusahaan dalam melaksanakan CSR, antara lain yaitu:

a. Keterlibatan langsung.

b. Melalui yayasan atau organisasi sosial perusahaan.

c. Bermitra dengan pihak lain.

d. Mendukung atau bergabung dalam suatu konsorsium.

Pelaksanaan CSR dapat dilaksanakan menurut prioritas yang didasarkan pada ketersediaan sumber daya yang dimiliki oleh perusahaan. Seperti dijelaskan Anne et.al (2005), bahwa ada dua pondasi yang menjadi dasar dari CSR, yaitu Charity Principle dan Stewardship Principle.

1. Charity Principle : Kegiatan yang dilakukan perusahaan untuk memberikan bantuan sukarela kepada seseorang atau kelompok yang membutuhkan.

2. Stewardship Principle : Tindakan perusahaan untuk mempertimbangkan kepentingan setiap pihak yang dipengaruhi oleh keputusan maupun kebijakan perusahaan (Rusdianto, 2013:15-16).

\section{Citra Perusahaan}

Menurut Farida (2009) dalam bukunya yang berjudul Manajemen Jasa Pendekatan Terpadu mendefinisikan citra sebagai representasi penilaian-penilaian dari konsumen, baik konsumen yang potensial maupun konsumen yang kecewa, dan termasuk kelompokkelompok lain yang berkaitan dengan perusahaan seperti pemasok, agen maupun para 
investor. Sedangkan, menurut Rhenald Kasali (2003) dalam bukunya menjelaskan bahwa citra perusahaan adalah sebuah cerminan dari identitas sebuah organsasi atau perusahaan, dalam sebuah perusahaan mampu memiliki beberapa citra yang berbeda-beda dimata publik.

Citra perusahaan merupakan citra dari suatu organisasi atau perusahaan secara keseluruhan, jadi citra perusahaan sendiri bukan hanya terdiri dari citra dari suatu produk dan pelayanan yang diberikan oleh suatu perusahaan saja, tetapi juga meliputi citra perusahaan secara menyeluruh. Ada beberapa hal yang dapat meningkatkan citra perusahaan, seperti sejarah atau riwayat hidup perusahaan yang gemilang, keberhasilankeberhasilan di bidang keuangan yang pernah diraih, reputasi sebagai pencipta lapangan kerja yang besar, kesediaan dalam memikul tanggung jawab sosial (CSR), komitmen mengadakan riset, dan sebagainya (Anggoro, 2000:59).

\section{Proses Terbentuknya Citra Perusahaan}

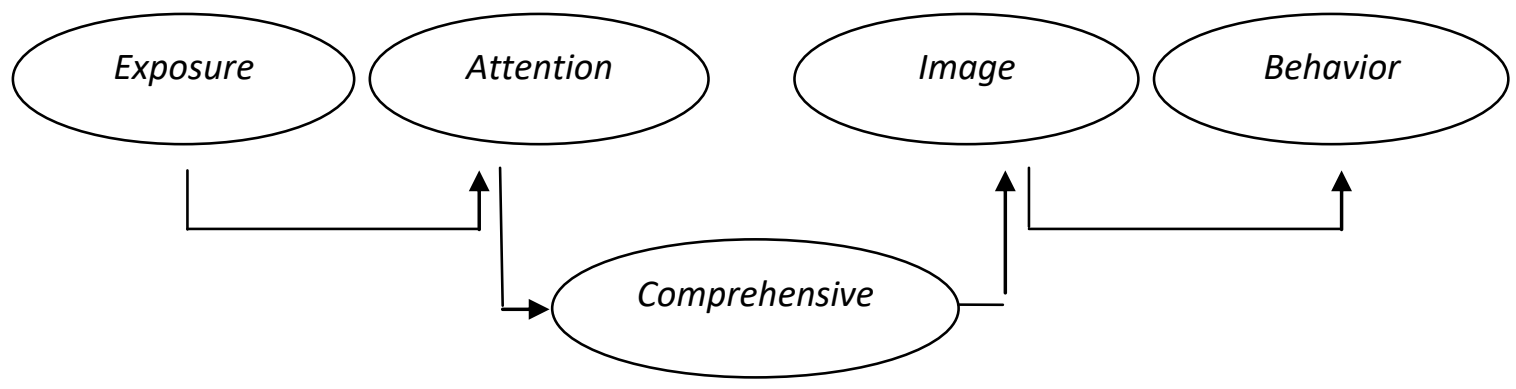

\section{Gambar 1.Proses Terbentuknya Citra Perusahaan}

Sumber : Hawkins et.al (2000) ConsumenBehavior:Building Market Strategy

Berdasarkan gambar 1, proses terbentuknya citra perusahaan menurut Hawkins (2000) berlangsung pada beberapa tahapan, yaitu:

1. Obyek mengetahui (melihat atau mendengar) upaya yang dilakukan perusahaan dalam membentuk citra perusahaan.

2. Memperhatikan upaya perusahaan tersebut.

3. Setelah adanya upaya perhatian obyek mencoba memahami semua yang ada pada upaya perusahaan.

4. Terbentuknya citra perusahaan pada obyek. 
5. Citra perusahaan yang terbentuk akan menentukan perilaku obyek sasaran dalam hubungannya dengan perusahaan.

Upaya perusahaan sebagai sumber informasi terbentuknya citra perusahaan memerlukan keberadaan secara lengkap. Informasi yang lengkap berguna sebagai informasi yang dapat menjawab kebutuhan dan keinginan obyek sasaran. Dengan kata lain, apabila sumber informasi yang disediakan tidak lengkap, maka pemahaman obyek tentang suatu perusahaan juga menjadi tidak lengkap, sehingga dapat menghasilkan citra perusahaan yang tidak sempurna (Kasali, 2003:28).

\section{Manfaat Citra Perusahaan}

Pada dasarnya, ada banyak manfaat yang diberikan jika suatu perusahaan memiliki citra yang positif, baik itu di kalangan para pemegang saham, investor, maupun masyarakat luas/khalayak umum. Menurut Irawan (2003) suatu perusahaan yang memiliki citra positif akan menerima manfaat sebagai berikut:

1. Menarik orang-orang yang berkualitas sehingga memiliki daya saing yang tinggi.

2. Perusahaan akan memperoleh kesempatan bisnis yang jauh lebih besar daripada perusahaan dengan citra yang buruk.

3. Persentase kesuksesan produk atau layanan baru yang diluncurkan dapat jauh lebih tinggi dibandingkan dengan perusahaan dengan citra di bawah rata-rata industri.

4. Program dan aktivitas pemasaran juga menjadi lebih efisien.

5. Para investor akan lebih percaya dan akhirnya akan berpengaruh terhadap harga saham terutama bagi perusahaan yang sudah go public

6. Loyalitas pelanggan akan meningkat dan mereka relatif tidak sensitif terhadap harga.

7. Perusahaan menikmati pertumbuhan pendapatan dan laba yang lebih baik 


\section{Hubungan Corporate Social Responsibility (CSR) Terhadap Citra Perusahaan}

Pada dasarnya setiap perusahaan dalam menjalankan setiap kegiatan operasionalnya memiliki tujuannya masing-masing, salah satunya adalah memperoleh keuntungan, meningkatkan citra perusahaan dan lain sebagainya. Tujuan perusahaan ini dapat dicapai oleh perusahaan melalui strategi penerapan CSR (Corporate Social Responsibility).

Ketika perusahaan menerapkan progrram tanggung jawab sosial sebagai salah satu strategi untuk meningkatkan citra perusahaan, tujuan mereka bukan hanya untuk mengejar keuntungan jangka pendeknya saja, namun juga turut berkontribusi bagi peningkatan kesejahteraan dan kualitas hidup masyarakat serta lingkungan di sekitar perusahaan tersebut untuk jangka panjang. Perusahaan yang menjalankan tanggung jawab sosialnya secara konsisten dan berkelanjutan (sustainable) akan menciptakan suatu sistem berupa "trust" dalam suatu lingkungan masyarakat. Sistem ini akan menciptakan respon yang positif masyarakat, rasa percaya dan kepuasan hati masyarakat terhadap perusahaan dan juga mampu mempererat hubungan antara perusahaan dan stakeholders. Dengan kata lain, semakin besar kontribusi perusahaan dalam melakukan tanggung jawab sosial (CSR) melalui berbagai program, maka citra perusahaan tersebut juga akan semakin baik di mata masyarakat yang berimbas pada reputasi perusahaan yang meningkat pula.

Menurut Untung (2008) jika perusahaan menerapkan CSR sebagai salah satu strateginya, pada awalnya perusahaan memang tidak akan mendapatkan profit atau keuntungan, tetapi dari kegiatan CSR tersebut itulah perusahaan akan memperoleh benefit berupa citra perusahaan. Jika perusahaan menerapkan CSR secara berkelanjutan atau sustainability, bukan tidak mungkin jika CSR dapat memberikan benefit yang signifikan terhadap perusahaan, termasuk juga benefit berupa profit atau keuntungan.

Jadi, secara keseluruhan keputusan perusahaan untuk melaksanakan CSR sebagai salah satu strategi untuk meningkatkan citra perusahaan secara berkelanjutan (sustainable), merupakan keputusan yang rasional. Sebab, implementasi program CSR akan menimbulkan efek lingkaran emas yang tidak hanya bermanfaat bagi perusahaan, melainkan juga stakehloder. Bila CSR mampu dijalankan secara efektif maka dapat memberikan manfaat tidak hanya bagi perusahaan, melainkan juga bagi masyarakat, pemerintah dan lingkungan. 


\section{METODE PENELITIAN}

Penelitian ini menggunakan metode penelitian kualitatif, dimana menurut Suharsimi (2014) metode penelitian kualitatif adalah metode penelitian yang berlandaskan pada filsafat positivisme, digunakan untuk meneliti pada populasi dan sampel tertentu. Penelitian yang menggunakan metode kualitatif memiliki tujuan untuk menggali dan membangun satu proporsi atau menjelaskan makna dibalik realita. Dengan begitu, dapat dikatakan bahwa penelitian ini dibuat bukan untuk menguji hipotesis antara kedua variabel, melainkan untuk mendeskripsikan sejauh manakah penerapan program CSR yang sudah dijalankan oleh PT. Pertamina (Persero) dapat berperan aktif dalam meningkatkan citra perusahaan tersebut.

Data yang dikumpulkan merupakan data yang diperoleh dari annual report PT. Pertamina (Persero) pada tahun 2018 yang diambil dari Indonesia Stock Exchange (IDX) dan website resmi PT. Pertamina (Persero), artikel serta dokumen lainnya. Teknik analisis data yang digunakan dalam penelitian ini menggunakan teknik analisis yang dikemukakan oleh Miles dan Huberman yang meliputi data collection (pengumpulan data), datareduction (reduksi data), datadisplay (penyajian data), dan conclusiondrawing/verification (penarikan kesimpulan) dan juga analisiskomparatif (membandingkan hasil temuan peneliti dengan teori yang digunakan). Jenis penelitian ini adalah penelitian deskriptif, yaitu sebuah penelitian yang memiliki tujuan untuk melihat gambaran atau deskripsi secara jelas mengenai kondisi tertentu dan merupakan penelitian yang menekankan pada data yang terkumpul untuk berbentuk kata-kata atau gambar, sehingga tidak menekankan pada angka, namun lebih menekankan pada proses dan makna.

\section{HASIL DAN PEMBAHASAN}

\section{Implementasi Program CSR PT. Pertamina (Persero)}

Sebagai salah satu perusahaan milik BUMN dan merupakan perusahaan energi nasional yang sudah berdiri selama lebih dari 60 tahun, PT. Pertamina (Persero) selalu berkomitmen untuk senantiasa memprioritaskan keseimbangan dan kelestarian alam, lingkungan dan masyarakat. Dengan menyejahterakan manusia, alam, dan lingkungan, maka PT. Pertamina 
(Persero) dapat mencapai pertumbuhan bisnis yang berkelanjutan. PT. Pertamina (Persero) tidak hanya berkomitmen untuk menciptakan nilai tambah bagi perusahaan tapi juga bagi masyarakat luas. Nilai tambah ini tidak hanya berupa energi sumber daya alam yang dirasakan oleh orang banyak melainkan juga "energi" positif lainnya, seperti akses terhadap pendidikan yang lebih baik, kemandirian ekonomi, serta pelestarian lingkungan, yang pada akhirnya untuk menuju kehidupan yang lebih baik, sesuai visi tanggung jawab sosial perusahaan atau Corporate Social Responsibility (CSR) Pertamina.

Komitmen yang ditetapkan oleh PT. Pertamina (Persero) ini sejalan dengan misi CSR perusahaan itu sendiri yang mencakup:

1. Melaksanakan komitmen korporat atas Tanggung Jawab Sosial dan Lingkungan (TJSL) yang akan memberikan nilai tambah kepada semua pemangku kepentingan untuk mendukung pertumbuhan perusahaan.

2. Melaksanakan tanggung jawab korporat dan kepedulian sosial untuk sebuah pembangunan masyarakat yang berkelanjutan.

Dalam menerapkan setiap program CSR, PT. Pertamina (Persero) juga berpegang pada prinsip CSR yang mereka miliki. Prinsip CSR PT. Pertamina (Persero) mengacu pada ISO 26000, yang berisikan:

1. Konsisten dengan pembangunan berkelanjutan dan kesejahteraan masyarakat.

2. Mempertimbangkan ekspektasi semua stakeholder.

3. Taat hukum dan konsisten dengan norma internasional.

4. Terintegrasi ke dalam bisnis.

Implementasi CSR PT. Pertamina (Persero) diwujudkan dalam beberapa program, seperti program pendidikan melalui Pertamina Cerdas yang sudah menyalurkan dana sosial kepada penerima Beasiswa Sobat Bumi sebanyak 1.157 orang di tahun 2018, program kesehatan melalui Pertamina Sehat yang menyediakan dan memberikan pemeriksaan kesehatan tanpa biaya bagi mereka yang membutuhkan, khususnyamereka yang berada pada remotearea dan wilayah 3T (Terluar,Terdepan, dan Tertinggal) sehingga mereka dapat meningkatkan akses kesehatan yang selama ini sulit didapatkan dengan mudah.

Sebagai perusahaan yang bergerak di industri ekstraktif, PT. Pertamina (Persero) juga 
memiliki program yang bertujuan untuk memberi manfaat kembali kepada alam. Program besar yang diusung PT. Pertamina (Persero) dalam kerangka memberikan kembali kepada alam adalah program Penanaman Mangrove dan Keanekaragaman Hayati dengan melakukan penanaman mangrove sebanyak 52.000 pohon di tahun 2018, konservasi elang laut di Kepulauan Seribu, konservasi tuntong laut di Aceh Tamiang, konservasi yaki hitam di Bitung, dan lainnya. Selain itu, melalui CSR PT. Pertamina (Persero) telah banyak menciptakan program-program yang mendukung terwujudnya ekonomi masyarakat lokal yang mandiri dengan membina lebih dari 100 Desa Binaan dan Kawasan Ekonomi Masyarakat di tahun 2018.

Ini membuktikan bahwa PT. Pertamina (Persero) memang benar-benar melakukan komitmennya sebagai perusahaan yang kegiatannya berkaitan langsung dengan alam dan membuktikannya melalui setiap program CSR, yang tidak hanya peduli pada masyarakat, tetapi juga pada lingkungan dan juga perkembangan berkelanjutan.

\section{Peran Program CSR PT. Pertamina (Persero) Sebagai Strategi untuk Meningkatkan Citra Perusahaan}

Tujuan strategis program CSR PT. Pertamina (Persero) adalah meningkatkan citra, reputasi dan kredibilitas perusahaan melalui kegiatan TJSL yang terintegrasi dengan strategi bisnis. Untuk mewujudkan tujuan ini, PT. Pertamina (Persero) mengimplementasikan strategi-strategi besar, seperti:

1. Saling memberi manfaat (fair shared value).

2. Berkelanjutan.

3. Memprioritaskan masyarakat di wilayah operasi dan daerah terkena dampak.

4. Pengembangan energi hijau sebagai tanggung jawab terhadap dampak operasi yang selaras dengan PROPER-LH.

5. Sosialisasi dan publikasi yang efektif.

Komitmen PT. Pertamina (Persero) dalam melaksanakan TJSL diwujudkan dalam berbagai kegiatan CSR yang meliputi bidang pendidikan, kesehatan, lingkungan, infrastruktur, pemberdayaan masyarakat, manajemen bencana, maupun bantuan khusus. Realisasi kegiatan dilaksanakan oleh seluruh unit kerja fungsi CSR PT. Pertamina 
(Persero), baik di kantor pusat, unit operasi, maupun anak perusahaan. Beberapa kegiatan khususnya di bidang pendidikan dilakukan bersama dengan Pertamina Foundation.

Di bawah payung tema "Pertamina Sobat Bumi", PT. Pertamina (Persero) mengimplementasikan program CSR untuk tujuan CSR yang sesuai dengan konsep Tripple BottomLine, yang meliputi people, planet, and profit (3P). Tujuan ini menjadi fokus PT. Pertamina (Persero) dalam menjalankan operasinya, di mana produk-produk yang dikembangkan dan jasa yang diberikan peduli terhadap kelestarian lingkungan khususnya bumi untuk kepentingan dan masa depan generasi yang akan datang.

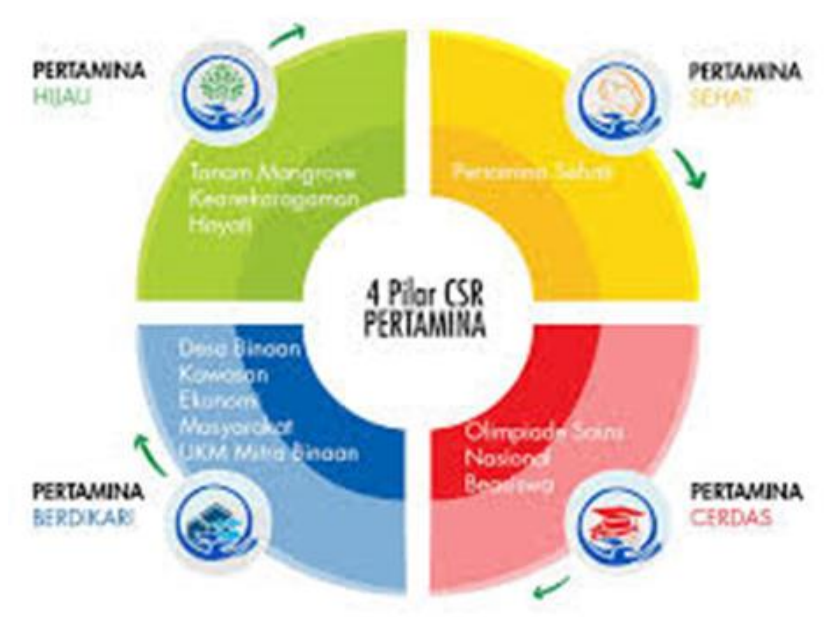

Gambar 2. 4 Pilar Utama CSR PT. Pertamina (Persero)

Sumber : Annual Report PT. Pertamina (Persero)Tahun 2018 (https://www.idx.co.id)

Berdasarkan komitmen serta tujuan yang ditetapkan oleh PT. Pertamina (Persero) dalam menerapkan CSR yang mereka miliki, ini menunjukkan bahwa program-program CSR yang dimiliki oleh PT.Pertamina (Persero) memang memiliki dampak yang baik untuk dijadikan sebagai strategi dalam meningkatkan citra perusahaannya. PT. Pertamina (Persero) menganggap bahwa prioritas mereka untuk meningkatkan citra perusahaannya adalah dengan bersinergi dengan masyarakat yang merupakan pemangku kepentingan eksternal yang menerima manfaat secara langsung dari Program CSR yang dilaksanakan, maka dari itu sinergi antara masyarakat dengan perusahaan merupakan kunci dalam keberhasilan program tersebut. Ini berarti bahwa dalam menerapkan CSR untuk meningkatkan citra perusahaan, strategi yang dilakukan oleh PT. Pertamina (Persero) adalah bersinergi dengan masyarakat untuk keberhasilan setiap program CSR yang telah dijalankan oleh PT. Pertamina (Persero). 
Dengan begitu, maka nantinya masyarakat bisa lebih mengetahui dan mengenal PT. Pertamina (Persero) dan secara tidak langsung lewat program CSR inilah, persepsi dan stigma positif mengenai perusahaan akan terbentuk yang berimbas pada meningkatnya citra PT. Pertamina (Persero) di depan publik.

\section{Citra Perusahaan PT. Pertamina (Persero)}

Strategi perusahaan dalam upaya mensosialisasikan setiap program dan juga kegiatan yang dilakukan oleh perusahaan menjadi poin penting dalam keberhasilan pesan yang ingin disampaikan terkait dengan pembentukan citra dan reputasi perusahaan. Dalam hal ini, PT. Pertamina (Persero) sudah melakukan penerapan strategi CSR dengan baik, mulai dari menyusun setiap program sesuai dengan konsep CSR yang sesuai sampai pada mensosialisasikan melalui berbagai media dan juga tindakan serta mengimplementasikan program CSR tersebut dengan baik. Ini dapat terlihat dari realisasi penyaluran dana di setiap programnya yang secara tidak langsung memenuhi segala aspirasi dan kebutuhan masyarakat yang memang sangat membutuhkan dana tersebut.

Dari CSR inilah, perusahaan ingin membentuk persepsi dan stigma positif masyarakat mengenai PT. Pertamina (Persero). Secara tidak langsung, perusahaan juga ingin meningkatkan citranya melalui pembentukan persepsi yang positif dari masyarakat ini dan menunjukkan kepada masyarakat mengenai nilai-nilai perusahaan yang menjadi karakteristik perusahaan itu sendiri. Dimana selain sebagai perusahaan yang menjalankan setiap kegiatan operasionalnya untuk mencapai suatu tujuan, yang salah satunya profit atau keuntungan, PT. Pertamina (Persero) juga tidak melupakan lingkungan di sekitarnya, dalam artian perusahaan masih sangat peduli dengan lingkungan dan masyarakat di sekitar mereka, baik di wilayah kantor pusat atau anak cabangnya. Karena bagaimanapun juga, perusahaan memiliki kewajiban dan tanggung jawab untuk menjaga lingkungan di sekitar usaha mereka tetap aman dan tidak menimbulkan dampak buruk serta kehidupan masyarakatnyapun tetap terjamin.

Tujuan strategis program CSR PT. Pertamina (Persero) adalah meningkatkan citra, reputasi dan kredibilitas perusahaan melalui kegiatan CSR yang mereka miliki, maka hal ini sudah dapat dibuktikan dengan banyaknya penghargaan atau rewards yang diperoleh PT. Pertamina (Persero) khususnya di tahun 2018. Salah satunya adalah penghargaan yang 
diberikan pada ajang TOP CSR Award 2018 yang merupakan ajang penilaian dan pemberian penghargaan (award) tertinggi kepada perusahaan yang beroperasional di Indonesia, yang dinilai telah menjalankan program CSR/PKBL/Community Development terbaik. Dalam ajang ini PT. Pertamina (Persero) berhasil mendapatkan 12 penghargaan terkait program CSR yang dilaksanakan pada berbagai sektor (https://www.pertamina.com). Ini menandakan bahwa strategi CSR yang diwujudkan ke dalam beberapa program, jika dijalankan dengan baik dapat meningkatkan citra perusahaan itu sendiri yang pastinya juga akan meningkatkan reputasi serta kredibilitas perusahaan tersebut.

\section{KESIMPULAN}

Berdasarkan hasil penelitian dapat disimpulkan bahwa penerapan strategi Corporate Social Responsibility (CSR) yang dijalankan oleh PT. Pertamina (Persero) sudah berjalan dengan baik dan berperan aktif dalam membentuk persepsi positif masyarakat untuk meningkatkan citra perusahaan. Hal ini menandakan bahwa pada dasarnya CSR memang memiliki pengaruh dalam meningkatkan citra perusahaan. Bukan citra perusahaan saja yang akan meningkat jika strategi CSR yang diwujudkan ke dalam beberapa program tersebut dapat diterapkan dengan baik dan tepat sasaran sesuai dengan tujuan program tersebut dibuat, melainkan juga akan berimbas kepada reputasi serta kredibilitas perusahaan yang akan meningkat pula.

Hal inilah yang terjadi pada PT. Pertamina (Persero), selain berhasil meningkatkan citra perusahaan mereka melalui penerapan CSR yang baik, mereka juga dapat memenuhi komitmen mereka untuk terus menjaga kelestarian lingkungan dan meningkatkan kesejahteraan masyarakat melalui pemberdayaan secara berkelanjutan.

Secara keseluruhan CSR yang PT. Pertamina (Persero) terapkan sudah berjalan dengan optimal dan sesuai dengan visi, misi, prinsip serta strategi CSR yang mereka miliki, terbukti dengan pengimplementasian program CSR yang terarah sehingga dapat memberikan input yang positif bagi perusahaan, baik itu peningkatan citra, reputasi, kredibilitas maupun perolehan rewards dari ajang penghargaan bergengsi.

Jadi, semakin besar kontribusi suatu perusahaan dalam melakukan tanggung jawab sosial, maka semakin baik pula citra perusahaan yang akan didapatkan. Semakin baik dan 
positif citra yang didapatkan oleh suatu perusahaan, maka reputasi dan kredibilitas perusahaan juga akan semakin meningkat.

\section{SARAN}

Adapun saran yang bisa diberikan agar PT. Pertamina (Persero) tetap dapat meningkatkan citra perusahaan mereka melalui penerapan strategi CSR adalah sebagai berikut:

1. PT. Pertamina (Persero) bisa mempertimbangkan untuk memperluas cakupan wilayah penerima program CSR yang dimiliki lebih jauh lagi, agar bukan hanya masyarakat yang berada di sekitar kantor pusat atau anak perusahaan saja yang bisa menerima manfaat dari setiap program CSR yang dijalankan, tetapi juga masyarakat secara keseluruhan.

2. PT. Pertamina (Persero) dapat mengembangkan program CSR menjadi lebih inovatif dan bervariasi lagi namun tetap dapat memenuhi kebutuhan di setiap pilar atau aspek yang menjadi komitmen utama penyelenggaraan CSR di PT. Pertamina (Persero) itu sendiri dan pastinya harus sesuai dengan konsep 3P.

\section{DAFTAR PUSTAKA}

Anggoro, Linggar M. 2000. Teori-teori dan Profesi Kehumasan: Serta Aplikasinya di Indonesia. Terbitan Pertama. Jakarta: Bumi Aksara.

Arikunto, Suharsimi. 2014. Prosedur Penelitian: Suatu Pendekatan Praktik. Yogyakarta: Rineka Cipta.

Hardiani. 2016. Pengaruh Corporate Social Responsibility (CSR) terhadap Brand Image (Citra Perusahaan)Studi Pada PT. Bank BRI Tbk (Persero) Cabang Makassar. Jurnal Imiah BONGAYA (Manajemen \& Akuntansi). April 2016, No.XIX.

Hawkins, D. I. et.al. 2000. Marketers Guide to Public Relation. New York: John Willyand Son.

https://www.idx.co.id: AnnualReport PT. Pertamina (Persero) Tahun 2018 (diakses pada tanggal 10 April 2020, pukul 14.35 WIB).

https://www.pertamina.com(diakses pada tanggal 12 April 2020, pukul 15.03 WIB). 
Irawan, Handi. 2003. Indonesian Customer Satisfaction: Membedah Strategi Kepuasan Pelanggan Merek Pemenang ICSA. Yogyakarta: Elex Media Komputindo.

Jasfar, Farida. 2005. Manajemen Jasa Pendekatan Terpadu. Cetakan Pertama. Bogor: Ghalia Indonesia.

Kasali, Rhenald. 2003. Manajemen Public Relation: Konsep \& Aplikasi di Indonesia. Jakarta: Pustaka Utama Grafiti.

Prasiska, Yosa Vega., Pertiwi, Bunga., Nabila, Yosi Rizky., Indah, Kristin., dan Safitri, Dian. 2017. CSR dan Citra Perusahaan. Jurnal Bisnis dan Ekonomi (JEB). Vol. 24, No. 1 Maret 2017. Fakultas Ekonomi dan Bisnis Universitas Muhammadiyah Magelang.

Rachman, Nurdin M, Asep Efendi dan Emit Wicaksana. 2011. Panduan Lengkap Perencanaan CSR. Cetakan 1. Jakarta: Penebar Swadaya.

Rachmawati, Tine Silvana. Program Corporate Social ResponsibilitySebagai Strategi Manajemen Kesan Perusahaan. 2019. Jurnal MetaKom. Vol. 3 No. 1 Juli 2019.

Rahadhini, MD. 2010. Peran Public Relations dalam Membangun Citra Perusahaan Melalui Program Corporate Social Responsibility. Jurnal Ekonomi dan Kewirausahaan. Vol. 10, No. 1 April 2010.

Rusdianto, Ujang. 2013. CSR Communucation A Framwork for PR Practitioners. Cetakan Pertama. Yogyakarta: Graha Ilmu.

Satya, Darma., dan Hidayatullah, Deden Syarif. 2018. Pengaruh Program Corporate Social Responbility Terhadap Citra Perusahaan (Studi pada PT. SUCOFINDO Tahun 2017). e-Proceeding of Management. Vol. 5, No. 2 Agustus 2018.

Ulum, Bahrul., Arifin, Zainul.,dan Fanani, Dahlan. 2014. Pengaruh Corporate Social Responsibility Terhadap Citra (Survei Pada Warga Sekitar PT. Sasa Inti GendingProbolinggo. Jurnal Administrasi Bisnis (JAB). Vol. 8, No. 1 Februari 2014.

Untung, Hendrik Budi. 2008. Corporate Social Responsibility. Jakarta: Sinar Grafika.

Vegawati, Silvania Mira., Kumadji, Srikandi., dan Fanani, Dahlan. 2015. Pengaruh Program Corporate Social Responsibilty (CSR) Terhadap Citra Perusahaan (Survey pada Warga di Desa Sidodadi Kelurahan Kalirejo Kecamatan Lawang Kabupaten Malang). Jurnal Administrasi Bisnis (JAB).Vol. 20 No. 1 Maret 2015. 